\title{
Prehistoric Birds and Bats from the Atiahara Site, Tubuai, Austral Islands, East Polynesia ${ }^{1}$
}

\author{
Trevor H. Worthy ${ }^{2}$ and Robert Bollt ${ }^{3,4}$
}

\begin{abstract}
The Austral Islands in French Polynesia have a depauperate land bird fauna and until recently have been little investigated archaeologically or paleontologically to know whether this is natural. Here we report an avifaunal assemblage and bones of bats of the genus Pteropus from the Archaic period (ca. A.D. 1000-1450) cultural site Atiahara, on Tubuai. Fifteen taxa are reported from the island, and a new species of rail in the genus Gallirallus is described. The data indicate that several petrel species have been extirpated from the island and that former land bird inhabitants included at least two small pigeons and a flightless rail.
\end{abstract}

The Austral Islands (Figure 1), French Polynesia (Maria Atoll, Rimatara, Rurutu, Tubuai, Raivavae, Rapa, and the Marotiri rock spires), have the smallest total landmass $\left(144 \mathrm{~km}^{2}\right)$ of any East Polynesian archipelago aside from the Pitcairn group $\left(43 \mathrm{~km}^{2}\right)$. They are high islands but too low to attract orographic rain, although because of their southern position there is abundant rainfall. Tubuai $\left(151^{\circ} \mathrm{W}\right.$ and $\left.23^{\circ} \mathrm{S}\right)$ has a landmass of $45 \mathrm{~km}^{2}$ and a maximum elevation of 409 $\mathrm{m}$. It is the largest of the Australs and consists of two main volcanic cores surrounded by a vast coastal plain. Encircling the landmass is a large lagoon with an area almost twice the size of the island itself.

The Austral Islands are, archaeologically, one of the least-studied archipelagoes in East Polynesia, but recent research is beginning to address this shortfall (Bollt 2005a,b, 2007, 2008, Kennett et al. 2006). On Tubuai, the

\footnotetext{
${ }^{1}$ Manuscript accepted 26 April 2010.

2 School of Biological, Earth, and Environmental Sciences, University of New South Wales, Sydney, New South Wales 2052, Australia (e-mail: t.worthy@unsw .edu.au).

3400 Hobron Lane, Apartment 1715, Honolulu, Hawai'i 96815.

${ }^{4}$ Deceased, 26 January 2010.
}

Pacific Science (2011), vol. 65, no. 1:69-85

doi: 10.2984/65.1.069

(C) 2011 by University of Hawai'i Press

All rights reserved
Atiahara site is the most important found so far. It was first excavated in the 1990s, the preliminary results of which were published in Eddowes (1998). The site is developed in an open, calcareous sand deposit with an Early Eastern Polynesian (EEP) or Archaic period (ca. A.D. 1000-1450) artifact assemblage that is contemporaneous with the Peva dune site on Rurutu (Bollt 2005a,b, 2007, 2008, Steadman and Bollt 2010), as well as with other sites in the southern Cooks (e.g., Allen 1992, Walter 1998). Diagnostic Archaic artifacts excavated from Atiahara include perforated tooth pendants, objects made of pearlshell (pendants, tattooing needles, coconut graters, harpoon tips, and a superb variety of one-piece fishhooks), and a wide array of adze types (e.g., Walter 1996).

The stratigraphy of the Atiahara site varies in complexity, becoming increasingly simpler toward the coast (north). Briefly, as outlined in Figure 2, beneath the topsoil (Layer A) there is a bed of calcareous sand (Layer B), the upper part of which has been turned by modern plowing. In the majority of the excavated area, the plow cuts have not penetrated deeply enough to disturb the Archaic cultural layer. The latest cultural layer (Layer C) exists either singly as a charcoal-stained deposit, or else in two or three sublayers (C1, C2, C3), closely superimposed one on top of the other and separated by thin lenses of windblown sand (Layer D). At the southern end of the excavation, another cultural layer beneath Layer C is evident (Layer E), which is a 


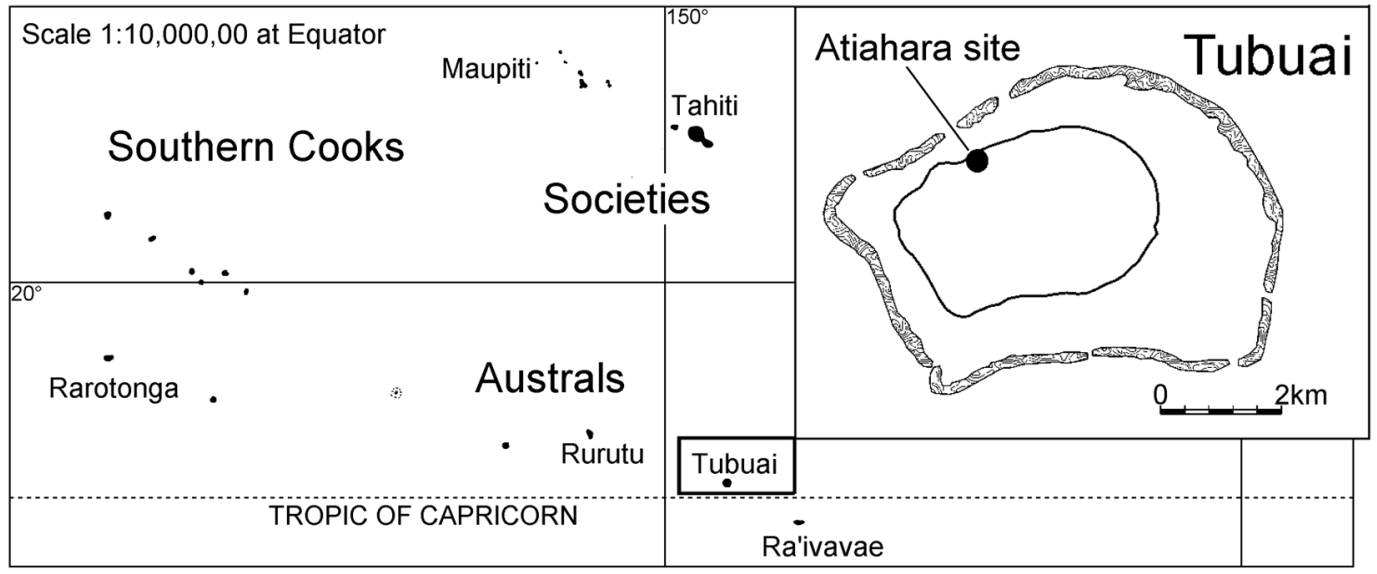

Figure 1. Central East Polynesia. Inset: Tubuai, showing surrounding barrier reef and location of the Atiahara site.

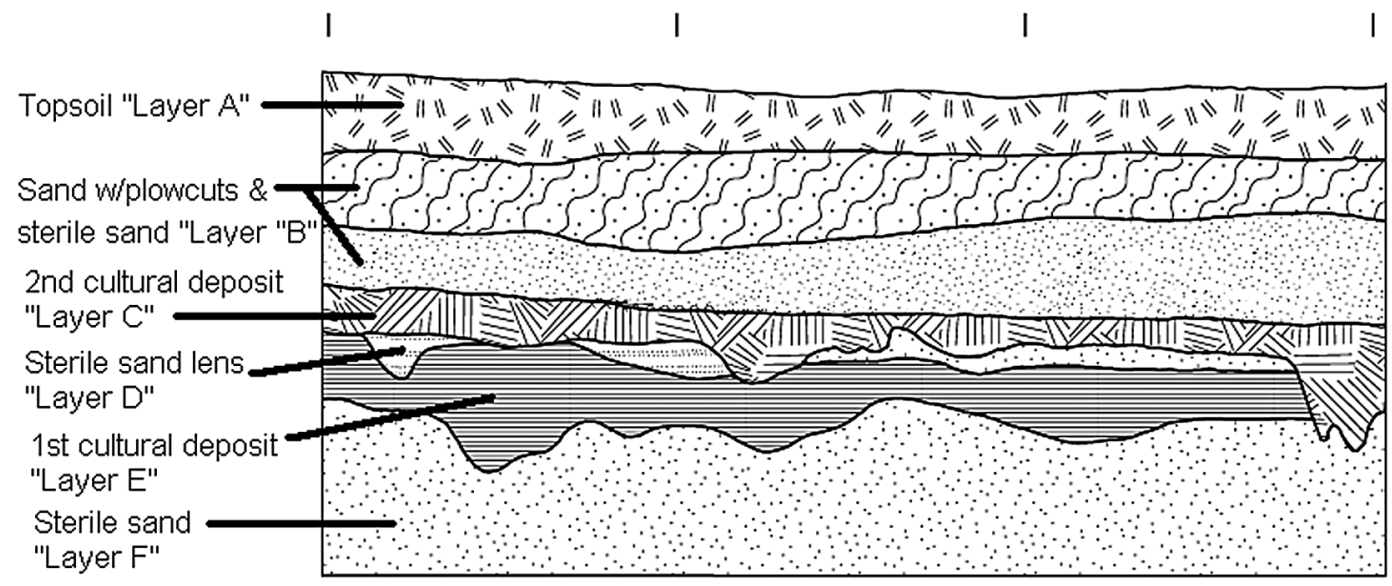

FIGURE 2. Representative wall profile of Atiahara stratigraphy.

denser, brown sand deposit, sometimes with a charcoal-stained sublayer beneath. The faunal assemblages from Layers $\mathrm{E}$ and $\mathrm{C}$ differ, suggesting two occupation periods. There is approximately four times more fish bone, shellfish, and bird bone in Layer $\mathrm{E}$ than in $\mathrm{C}$, but in $\mathrm{C}$ there is two to three times the amount of domesticated animal (primarily pig) bone than in Layer E. However, the artifacts from both layers are typologically identical. Beneath the cultural layers, sterile sand (Layer F) continues for a depth of about 1 $\mathrm{m}$ until the coral hardpan is reached.
In total, the cultural layers yielded hundreds of Archaic artifacts including adzes and stone tools, fishhooks, and diagnostic ornaments and other tools; many basalt debitage flakes were found as well, in addition to hundreds of pieces of worked pearlshell (R.B., unpubl. data). Numerous hearths, fire pits, and earth ovens provided samples of wood charcoal and marine shell suitable for radiocarbon dating. The site has revealed the largest collection of faunal remains from the archipelago, consisting of thousands of fish bones, much shell, and thousands of whole 
and fragmentary bones of pig, dog, chicken, rat, turtle, marine mammal, and flying fox (Pteropus). The cultural layers, with many postholes and pits, appear to have been a series of one or more habitation sites, probably occupied over a period of several generations (R.B., unpubl. data). Upon the Atiahara site, activities included food preparation, cooking, adze making, and the manufacturing of pearlshell fishhooks and other bone and shell tools.

\section{Prebistoric Record of Birds}

Before our study, the only prehistoric land birds known from the Austral Islands were from a small excavation at the Atiahara site, Tubuai, by Richard Shutler in 1995 and the Peva site on Rurutu (Steadman and Bollt 2010). The bones from Atiahara are dominated by fish (Steadman 2006: tables 7-11). That bird bones were few $(0.2 \%$ of the number of individual specimens) and pig bones were nearly as frequent as rat bones suggests that recovery of small bones at Atiahara in 1995 was less complete than at Peva. The 11 bird bones from the Atiahara site provide the only glimpse of Tubuai's prehistoric avifauna (Steadman 2006: tables 7-12, Table 3 herein). These few bones revealed a fruitdove (Ptilinopus undescribed sp.) by a nearly complete tibiotarsus that differs much from those of the geographically nearest congeneric species, $P$. rarotongensis on the Cook Islands and P. buttoni to the southeast on Rapa.

The only other prehistoric bird bones known from the Austral Islands are 12 associated bones of a petrel from a small species of Pterodroma the size of $P$. nigripennis or $P$. cookii from a noncultural context in Coconut Cave on Rurutu (Steadman 2006).

In the nineteenth century the Australs and the southern Cooks were so famous for their parakeet feathers that Tahitians called them the Paroquet [parakeet] Islands or Fenua-'ura ("Red land") (Henry 1928:464). The name "Red land" is most likely derived from Kuhl's Lorikeet (Vini kublii), also called the Rimatara Lorikeet (Pratt et al. 1987), because it had been regarded as endemic to that island. Species of Vini were likely found throughout the Cooks and Australs in prehistory. In fact, three species of Vini are known to have occurred on single islands in the Cooks, Societies, and Marquesas that have respectable records of prehistoric birds (Steadman 2006). In the southern Cook Islands, V. kublii is known prehistorically from Atiu and Mangaia, with Mangaia also having the two larger, extinct species $V$. vidivici and $V$. sinotoi, which are known only from bones in Archaic middens or precultural deposits (Steadman 1991, 2006).

The indigenous land bird fauna of the Austral Islands is now depauperate, with only three endemic taxa (Steadman 2006: tables 710): the Rapa fruit dove, Ptilinopus buttoni; Kuhl's lorikeet, $V$. kublii on Rimatara; and the Rimatara Reed Warbler, Acrocephalus vaughani. Four widespread species are also present: three semiaquatic tramp species, a heron, Egretta sacra; a duck, Anas superciliosa; and a rail, Porzana tabuensis; and a winter visitor, the long-tailed cuckoo, Eudynamys taitensis (Aitken 1930, Ehrhardt 1980, Steadman 2006). On Tubuai, the avifauna is now even more depauperate (Table 1).

A key question relates to the former presence of the Pacific Flying Fox (Pteropus tonganus), now absent from the Australs. During the Archaic period this species was extirpated on neighboring Rurutu (Weisler et al. 2006, Bollt 2007, 2008), as well as on islands in the southern Cooks (Allen 1992, Walter 1998); it still exists on two islands in the latter group (Mangaia and Rarotonga). Finding this species on Rurutu has extended its eastern limit in the Pacific by hundreds of kilometers. There is a strong possibility that humans transported it eastward (Weisler et al. 2006); alternatively, Rurutu and the Australs may have been part of the natural range of $P$. tonganus. If Pteropus is lacking from levels before human presence on Tubuai, then the hypothesis of human transport would be corroborated.

Here we extend knowledge of the prehistoric fauna of the Austral Islands by describing a noteworthy avifauna and Pteropus bones in the Atiahara assemblage excavated during 3 November to 24 December 2007 by R.B. 
TABLE 1

Birds Currently Found in the Tubuai Fauna after Aitken (1930), Ehrhardt (1980), Steadman (2006), and Thibault and Bretagnolle (2007)

\begin{tabular}{ll}
\hline \hline Scientific Name & \multicolumn{1}{c}{ Common Name } \\
\hline Oceanic and coastal & \\
species & \\
Pterodroma ultima & Murphy's Petrel \\
Puffinus nativitatis & Christmas Shearwater \\
Puffinus pacificus & Wedge-tailed Shearwater \\
Gygis alba & White Tern \\
Anous stolidus & Brown Noddy \\
Anous minutus & Black Noddy \\
Fregata minor & Great Frigatebird \\
& (nonbreeding) \\
Fregata ariel & Lesser Frigatebird \\
& (nonbreeding) \\
Sula leucogaster & Brown Booby \\
Phaethon lepturus & White-tailed Tropicbird \\
Phaethon rubricauda & Red-tailed Tropicbird \\
Heteroscelus incanus & Wandering Tattler \\
Pluvialis fulva & Pacific Golden-Plover \\
Indigenous taxa & \\
Anas superciliosa & Pacific Black Duck \\
Egretta sacra & Pacific Reef-Heron \\
Porzana tabuensis & Spotless Crake \\
Migratory species & \\
Calidris alba & Sanderling \\
Eudynamys taitensis & Long-tailed Koel \\
Limosa lapponica & Bar-tailed Godwit \\
Numenius tabitiensis & Bristle-thighed Curlew \\
Introduced species & \\
Acridotheres tristis & Common Myna \\
Gallus gallus & Red Junglefowl \\
Lonchura castaneothorax & Chestnut-breasted \\
& Mannikin \\
Zosterops lateralis & Silvereye \\
\hline & \\
& \\
& \\
& \\
&
\end{tabular}

MATERIALS AND METHODS

From 3 November to 24 December 2007, R.B. directed a new excavation of the Atiahara site with a team consisting of 10 student and professional volunteers from Hawai $i$, the University of Otago, the University of Auckland, and the Australian National University. In total, they excavated over $130 \mathrm{~m}^{2}$ of pristine ground in untouched areas surrounding the original bulldozed trench and previously dug areas. Numerous hearths, fire pits, and earth ovens provided samples of wood charcoal and marine shell suitable for radiocarbon dating. Sediments were dry-screened using $3.2 \mathrm{~mm}$ (1/8 inch) mesh; additional samples were screened for land snails using $1 \mathrm{~mm}$ mesh and wet screening. The large collection of faunal remains included over 25,000 fish bones, over $300 \mathrm{~kg}$ of shell, and thousands of whole and fragmentary remains of pig, dog, chicken, rat, turtle, marine mammal, and flying fox. Bird remains were sorted from these in the laboratory and sent to T.H.W. They were identified by T.H.W. after comparison with reference skeletons in the South Australian Museum, Adelaide, and Australian Museum, Sydney. The anatomical nomenclature used for specific bone landmarks when describing specimens follows Baumel and Witmer (1993). We follow the taxonomic sequence and nomenclature advocated by Gill et al. (2010).

Important comparative specimens are listed where relevant. Measurements were made with dial calipers (Tesa) to $0.1 \mathrm{~mm}$.

\section{Radiocarbon Dating}

Two samples of charred bark were chosen for dating because this medium does not suffer from problems of inbuilt age, as is potentially an issue with wood charcoal, and neither does it have the problems of bone where the collagen fraction weathers away rapidly in tropical environments and exclusion of humic acid and other contaminants is problematical. The radiocarbon analyses were determined at the Australian National University Radiocarbon Laboratory, Canberra, using the Single Stage Accelerator Mass Spectrometer.

Abbreviations: AM, Australian Museum, Sydney; F, female; M, male; MNI, minimum number of individuals; NISP, number of individual specimens. Elements: cmc, carpometacarpus; hum, humerus; fem, femur; juv, juvenile; rad, radius, tib, tibiotarsus; tmt, tarsometatarsus; M, male; F, female; L, left; R, right. $\mathrm{L}$ and $\mathrm{R}$ preceded by $\mathrm{p}, \mathrm{s}$, or $\mathrm{d}$ indicate the proximal, shaft, or distal part of the element, respectively. We use the term "magn." (from Latin, magnitudino) to indicate that the taxon is the approximate size of the following listed modern species. 
RESULTS

\section{Dating}

Two radiocarbon dates were obtained from a C-layer pit fill in the 2007 excavation: (1) Laboratory code SSAMS 7120, submitter's sample identification TVB624, excavation unit K5 Hole, 200-210 cm depth, charred bark, conventional radiocarbon age $930 \pm 60$ yr B.P., calibrated age 686-921 yr B.P.; (2) SSAMS 7138, TVB633, excavation unit K5 Pit Fall, 175-180 cm depth, charred bark, conventional radiocarbon age $855 \pm 30 \mathrm{yr}$ B.P., calibrated age $675-769$ yr B.P. (Calibrations from SH curve using Calib 5.0.)

\section{SYSTEMATIC ACCOUNT}

Class Mammalia

Family Pteropodidae

Pteropus tonganus tonganus, Tongan Fruit Bat MATERIAL: Right dentary with $\mathrm{m} 2$ (Unit
L5, Layer E [Figure 3]); L dentary with $\mathrm{m} 2$ (Unit ?, Layer C).

Comparisons were made with: Pteropus samoensis, Ам M.23231, F; Ам M.23238, F, both Vanua Levu, Fiji. P. tonganus geddiei, AM M.27167, M, Vanuatu. P. tonganus tonganus, aм M.23219, F; aм M.23216, F, both Fiji. $P$. vetulus, ам M.24454, New Caledonia. The size of the Tubuai specimens is similar to that of $P$. samoensis and $P$. tonganus tonganus (Table 2). Pteropus tonganus geddiei is significantly larger (Flannery 1995) as exemplified by M.27167 in Table 2. Pteropus vetulus is a much smaller fruit bat. The Tubuai specimens are referred to $P$. tonganus tonganus on the basis of the morphology of $\mathrm{m} 2$. The fossil has a short and wide $\mathrm{m} 2$ with well-rounded cusps buccally and lingually of the shallow central basin of the molar with no distinct posterior buccal cusp. Those of $P$. samoensis are more elongate, have relatively sharp crests buccally and lingually, and have a distinct posterior buccal cusp separated by a notch from the more anterior buccal cusp.

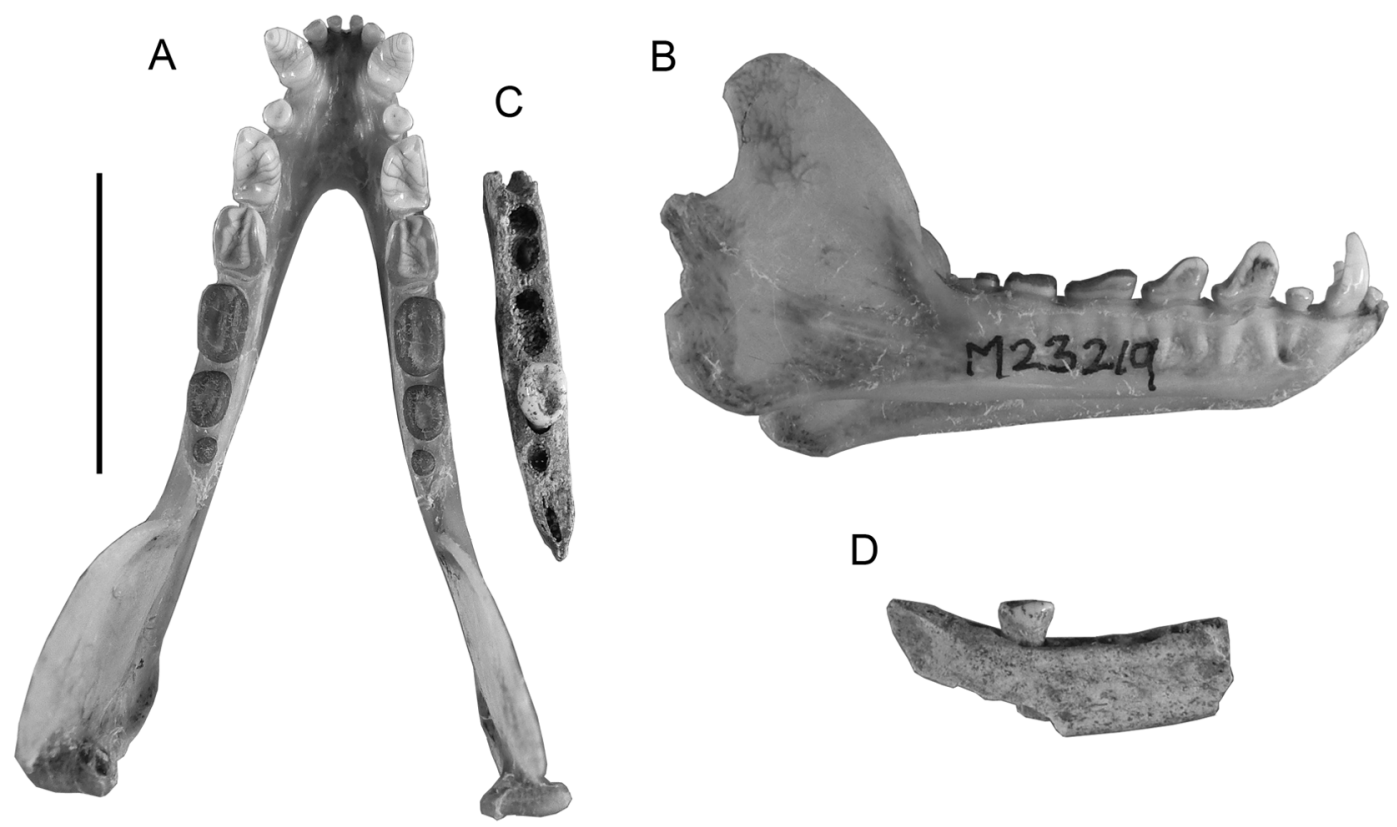

Figure 3. Mandible of Pteropus tonganus tonganus, am M.23219, in dorsal view $(A)$ and right lateral view $(B)$ compared with the Tubuai specimen from Unit L5, Layer $\mathrm{E}(C, D)$. Scale bar is $20 \mathrm{~mm}$. 
TABLE 2

Measurements (mm) of Mandibles of Various Pteropus Species Compared with the Tubuai Specimen

\begin{tabular}{lcccc}
\hline \hline Taxon & Cat. No./ID & Depth $1^{a}$ & Length m2 & Width m2 \\
\hline Tubuai specimen & L5/E & 6.7 & 3.6 & 2.8 \\
P. samoensis & M.23231 & 6.7 & 3.3 & 2.4 \\
P. samoensis & M.23238 & 6.4 & 3.5 & 2.4 \\
P. tonganus geddiei & M.27167 & 8.8 & 3.8 & 3.5 \\
P. tonganus tonganus & M.23219 & 6.2 & 3.3 & 2.5 \\
P. tonganus tonganus & M.23216 & 6.3 & 3.2 & 2.5 \\
\hline
\end{tabular}

Abbreviations: Cat. No., catalog number in the mammal collection, Australian Museum; ID, excavation identification; m2, mandibular molar 2.

${ }^{a}$ Depth of mandible below alveolus for molar 1.

\section{BIRDS}

In Material lists, the catalog number in the Ornithology collection of the Australian $\mathrm{Mu}-$ seum is followed by the unit or excavation square, the layer or origin, and the element for each specimen.

\section{Order Galliformes \\ Family Phasianidae}

\section{Gallus gallus, Chicken}

MATERIAL: AM O.72463, Unit G3, Layer C1, sL tmt; Aм O.72464, H5, Layer C, pL cmc; Ам O.72484, H3, Layer F, dL tmt; Ам O.72485, Q4, Layer E, pL tmt; Ам O.72535, L12, Layer F, pL rad. cf. Gallus gallus: AM O.72529, L12, Layer F, juv. dL tmt. Total $5+? 1$ specimens, 2 individuals.

\section{Order Procellarifformes \\ Family Procellaritdae}

Pterodroma sp. magn. P. macroptera, Grayfaced Petrel

MATERIAL: AM O.72480, G2, Layer E, dR hum.

This specimen lacks the condylus dorsalis and has a shaft width at the proximal side of the processus supracondylar dorsalis of 7.9 $\mathrm{mm}$. It does not differ in any way from a specimen of P. macroptera, AM O.58521, and so is tentatively referred to that taxon. Pterodroma macroptera ranges to about $130^{\circ} \mathrm{W}$ between $30^{\circ}$ and $50^{\circ} \mathrm{S}$ (Gill et al. 2010) so may well be expected in waters around the Austral Islands.
Pterodroma sp. magn. P. neglecta, Kermadec Petrel

material: am O.72449, K3, Layer C, $\mathrm{dL}$ tib, pL tmt of a juvenile/fledgling. Proximal width $\mathrm{tmt}=6.7 \mathrm{~mm}$, distal width tib $=$ $5.48 \mathrm{~mm}$.

Pterodroma neglecta has a wide breeding distribution from Lord Howe Island and the Kermadecs to the Juan Fernández Islands far to the east of the Austral Islands. It still breeds on Rapa and Raivavae in the Australs (Thibault and Bretagnolle 2007). Several other tropical Pacific species are similar in size to the Kermadec petrel, and the fossils could potentially belong to any of them: $P$. cervicalis, White-naped Petrel; P. alba, Phoenix Petrel; P. beraldic, Herald Petrel; and $P$. atrata, Henderson Petrel. Regardless of their identity, these two bones are evidence of a medium-sized Pterodroma species formerly breeding on Tubuai.

Pterodroma sp. magn. P. brevipes, Collared Petrel

MATERIAL: am O.72440, L1, Layer C, pL ulna; Ам O.72450, T/V1, Layer C, R cmc; Aм O.72466, T4, Layer C1/2, dL hum; AM O.72518, F/G, Layer ?, sR hum; AM O.72519, J4, Layer E, sL ulna; Aм O.72521, K12, Layer F, dL ulna; Aм O.72528, X3, Layer E, RdR ulna, d cmc. Nine specimens; MNI, 2.

Several similar-sized small petrels are found in the tropical Pacific (e.g., Onley and Scofield 2006). Gould's Petrel, Pterodroma 
leucoptera, with $P$. l. leucoptera breeding on Cabbage Tree Island, Tasman Sea, and P. $l$. caledonica in New Caledonia, migrates to the tropical eastern Pacific (Gill et al. 2010). The Collared Petrel, Pterodroma brevipes, sometimes considered a subspecies of $P$. leucoptera and now rare and endangered, breeds in South Vanuatu, Makira (Solomon Islands), Fiji, Western Samoa, Rarotonga (Cook Islands), Raivavae in the Austral Islands (Thibault and Bretagnolle 2007), and was historically known breeding in Tahiti and Samoa (Onley and Scofield 2006). Black-winged Petrel, Pterodroma nigripennis, breeds on islands in the Tasman Sea and on islands around New Caledonia and New Zealand, Tonga, Rarotonga, to as far east as Rapa in the southern Austral Islands. It has an expanding distribution (Gill et al. 2010) but has a more southern range than $P$. brevipes. All have wider nonbreeding distributions.

On the basis of the morphology of postcranial elements none of these taxa can be separated, but given that $P$. brevipes is still breeding in the northern part of the Austral group, we think it more likely that the bones listed here belong to that species.

Puffinus sp. magn. P. pacificus, Wedge-tailed Shearwater

MATERIAL: AM O.72468, N13, Layer C, sR tib.

This specimen is a fragment of shaft preserving all of the fibular crest. The length of the fibular crest is ca. $18 \mathrm{~mm}$, and shaft width below the fibular crest is $3.9 \mathrm{~mm}$. It is more slender than in Puffinus tenuirostris (e.g., AM O.59307, O.57724), which had shaft widths of 4.2 and $4.3 \mathrm{~mm}$. Puffinus pacificus is widespread in the tropical western Pacific (Thibault and Bretagnolle 2007) and varies in size, but this specimen matches am O.58459 (fibular crest $19.5 \mathrm{~mm}$ long, shaft width 4.1 $\mathrm{mm}$ ) though others are smaller (e.g., AM O.65692 [fibular crest $15.2 \mathrm{~mm}$, shaft width $3.5 \mathrm{~mm}])$.

Puffinus sp. magn. P. lherminieri, Audubon's Shearwater

The phylogenetic relationships of small tropical shearwaters are currently poorly understood (Austin et al. 2004). The major checklists recognize only a few species, with $P$. lherminieri being used for most tropical populations and $P$. assimilis for most higherlatitude populations (e.g., Warham 1990, Carboneras 1992). Genetic data from a comprehensive sampling of taxa reveal a much more complex situation in which the widespread form in the tropical Pacific, P. l. dichrous, and P. l. polynesiae from Ta' $\bar{u}$, American Samoa, constitute part of a distinct lineage including Indian Ocean forms that would take the name $P$. bailloni (Tropical Shearwater), with P. lherminieri (Audubon's Shearwater) restricted to the Atlantic Ocean and $P$. assimilis to Australasia (Austin et al. 2004). The situation is further complicated by the small shearwater $P$. assimilis myrtae described from Rapa Island, in the southern Austral Islands (Bourne 1986, Thibault and Bretagnolle 2007). Molecular data suggest that this extant population is more closely related to Puffinus newelli of Hawai'i, and that it may be of hybrid origin (Austin et al. 2004). It is doubtful that the fragmentary material from Tubuai could be certainly identified, so pending clarification of the taxonomy we refer these specimens to Puffinus sp. magn. P. lherminieri to indicate the size class to which they belong. MATERIAL: AM O.72447, O5, Layer C, dR hum; AM O.72448, I5, Layer C, dL hum; Aм O.72511, F/G3, Layer F, dR hum; AM O.72514, R2, Layer D/E, pR hum; AM O.72515, F/G2, Layer G, pL hum; AM O.72517, X2, Layer F $(150-160 \mathrm{~cm})$, dL hum; Aм O.72523, I2, Layer F, pR hum; AM O.72524, T9, Layer E, pL hum; AM O.72532, R3, Layer E/F, sR tib, sL hum; AM O.72525S4, Layer E, dRdL hum, pR ulna; Aм O.72512, T4, Layer E, dR ulna; AM O.72513, L13, Layer F, pR ulna, sR tib; AM O.72515, L10, Layer F, dL ulna; AM O.72520, L15, Layer E, sL ulna; AM O.72527, Q3, Layer E, sR hum. Nineteen specimens; MNI, 3 individuals.

\section{Family Phaethontidae}

Phaethon lepturus, White-tailed Tropicbird MATERIAL: AM O.72534, K12, Layer E, dR ulna; Aм O.72533, N15, Layer E, R cor. 
A

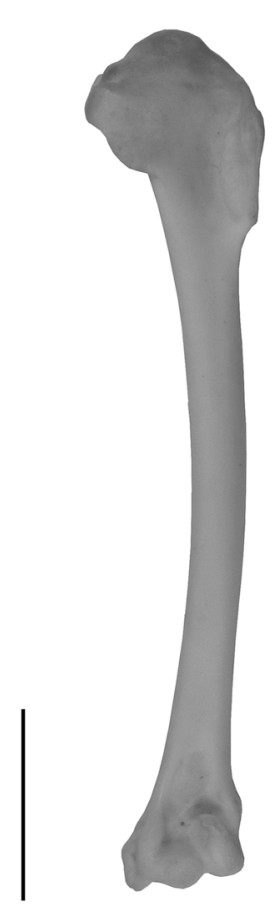

B

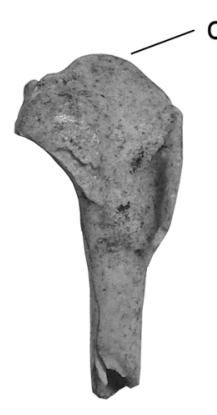

C

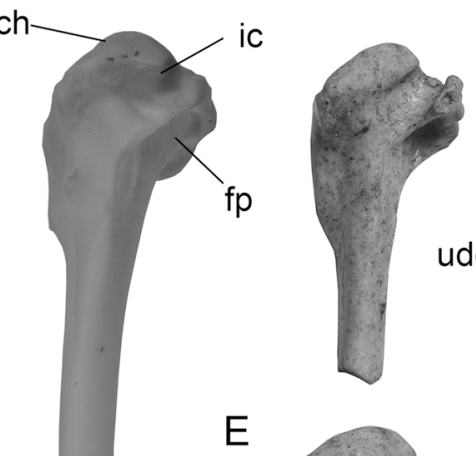

E

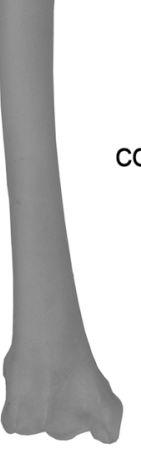

\section{F G}

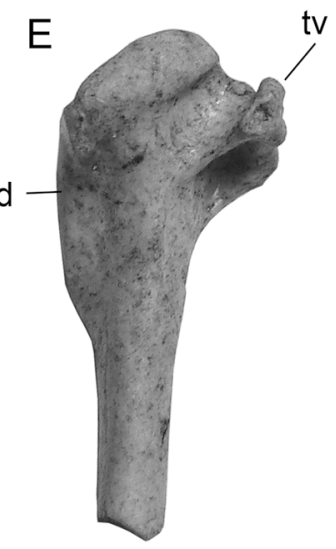

tv
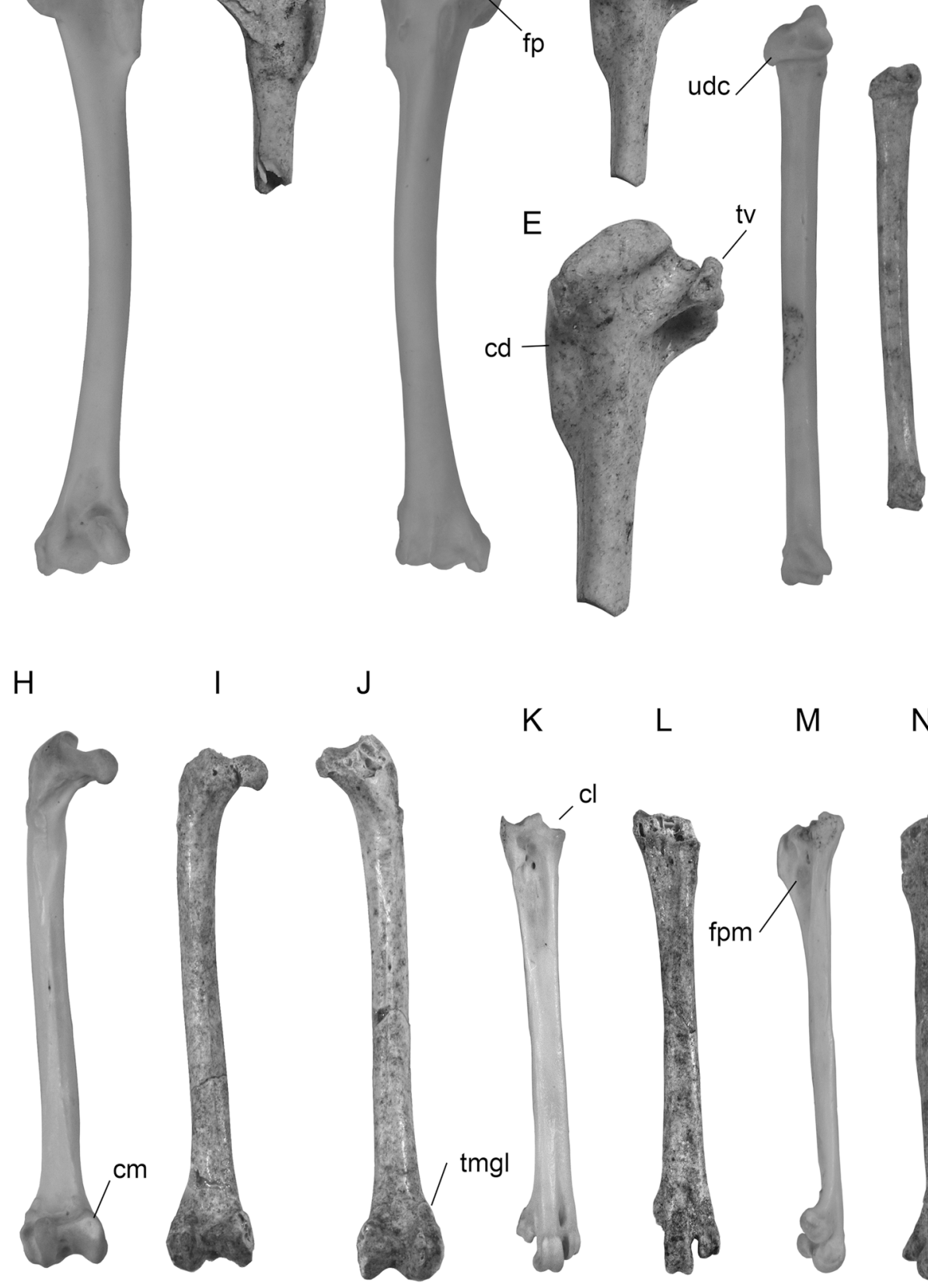

L

M

$\mathrm{N}$
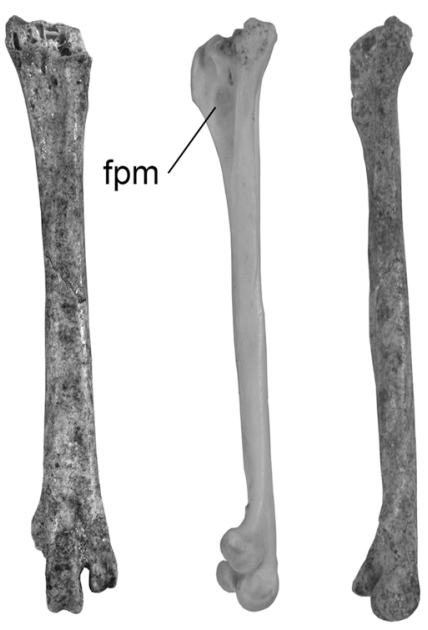

Figure 4. Selected elements of Gallirallus philippensis $(A, C, F, H, K, M)$ compared with Gallirallus steadmani Worthy \& Bollt, n. sp. $(B, D, E, G, I, \mathcal{F}, L, N)$. Left humeri in cranial $(A, B)$ and caudal aspect $(C-E)$; right ulnae in cranial aspect; femora (left $H, I$; right $\mathcal{F}$ ) in ventral aspect; and left tarsometatarsi in dorsal $(K, L)$ and medial $(M, N)$ aspects. Abbreviations: cd, crista deltopectoralis; ch, caput humeralis; cl, cotyla lateralis; cm, condylus medialis; fp, fossa pneumotricipitalis; fpm, fossa parahypotarsalis medialis; ic, incisura capitis; tmgl, tuber. m. gastrocnemialis lateralis; tv, tuberculum ventrale; udc, ulnar cotyla dorsalis. Scale bar is $10 \mathrm{~mm}$ except for $E$, which is $1.5 \times$ others in row. 
cf. Phaethon lepturus: ам O.72465, D2, Layer C, sL hum; Aм O.72441, F1, Layer C, pR ulna. Total $2+$ ?2 specimens, 1 individual.

\section{Order Gruiformes \\ Family Rallidae \\ Genus Gallirallus Lafresnaye, 1841}

The fossils listed in this section are referred to Gallirallus, sensu Kirchman and Steadman (2006a) and Steadman (2006), rather than to other genera of rails found in the Pacific Ocean region because they have the following combination of characters (modified from Kirchman and Steadman [2006a] and Worthy [2004]). Humerus: fossa pneumotricipitalis deepened ventroproximally with prominent crus ventrale fossae. Ulna: thin in cranial aspect, craniocaudally wider than dorsoventral depth, ventral facies flattened with angular junction with margo cranialis. Femur: distal half of corpus femoris gradually widening distally; condylus medialis in medial aspect not circular, somewhat angular caudally; caudal impressio ansa musculus iliofibularis (sensu Baumel and Witmer 1993: note 260; not as per Livezey and Zusi 2006: char 2050) is distally adjacent to the trochlea fibularis and proximally abuts the larger round tuberculum m. gastrocnemialis lateralis. Tibiotarsus: impressio ligamentum collateralis medialis deep and wide; medial and lateral margins of facies cranialis rounded (not angular); facies cranialis convex rather than flattened in distal half; sulcus extensorius about $1 / 3$ shaft width, narrowly separated from medial margin; depressio epicondylaris lateralis deep; condylus medialis in medial aspect not circular, with caudocranial depth greater than proximodistal depth. Tarsometatarsus: length less than femur length; corpus tarsometatarsi much wider than deep; fossa parahypotarsalis medialis shallow; fossa metatarsi I short and shallow; crista medianoplantaris slopes gradually from hypotarsus to shaft (not abruptly, nor hooked distally); cotyla medialis is rectangular in proximal aspect with flattened dorsal margin; cotyla medialis distinctly proximal to lateral cotyla.

The gallinules (Gallinula ventralis, G. tenebrosa, and G. mortierii) and the swamphens
(Porphyrio spp.) all differ markedly from Gallirallus in having the tarsometatarsus markedly longer than the femur, in addition to some of the features listed here. Other rails such as Amaurornis olivacea and Poliolimnas cinereus also differ in having the tarsometatarsi more elongate than the femora. However, the crakes included in Porzana found in Oceania (e.g., P. tabuensis and P. pusilla) have the tarsometatarsus shorter than the femur but are smaller than species of Gallirallus and also differ in having the distal portion of the tibiotarsus flattened anteriorly, with the medial and lateral margins angular, the fossa metatarsi I of the tarsometatarsus deeper, and the hypotarsus more elongate.

The following species was flightless, thus precluding dispersal over hundreds of kilometers of ocean, so it is assumed to have evolved on Tubuai from a volant ancestor, as have many rails in Oceania (e.g., Slikas et al. 2002, Steadman 2006, Kirchman and Steadman 2006a). It is thus unlikely to be conspecific with flightless rails elsewhere, so we have limited our comparisons mainly to the widespread volant $G$. philippensis.

Gallirallus steadmani Worthy \& Bollt, n. sp. Figure 4; Table 3

Holotype: AM O.72500, proximal left humerus, preserving part of the shaft and the entire proximal end, stained a light brown but otherwise undamaged. Preserved length $18.0 \mathrm{~mm}$, maximum proximal width $8.3 \mathrm{~mm}$, craniocaudal depth at tuberculum ventrale $5.1 \mathrm{~mm}$, length of crista deltopectoralis 8.6 $\mathrm{mm}$, and minimum shaft width in caudal view $2.3 \mathrm{~mm}$.

PARATYPES: AM O.72470, pL humerus, K2, Layer F; Aм O.72490, R ulna, L11, Layer F; AM O.72504, L tarsometatarsus joined from two halves, $\mathrm{H} 2 / \mathrm{H} 3$, Layer F; $\mathrm{AM}$ O.72458, R femur joined from two halves, N13, Layer C; Ам O.72476, L femur, N14, Layer F.

TyPe locality: The Atiahara archaeological site, square L11, Layer F, Tubuai, Austral Islands. Collected by R. Bollt et al. during 3 November to 24 December 2007. 
REFERRED MATERIAL: Layer A/B: AM O.72444, unit L4, dL tib.

Layer C: Ам O.72455, C2/C3, L fem (-d); Ам O.72454, D3, dL fem; Ам O.72442, E1, pR tib; Ам O.72443, F4, dL tib; Ам O.72456, G1, dLdR tib; Ам O.72461, G4, dL tib; Aм O.72446, I4, juv R tmt; AM O.72452, I5, pR tib; ам O.72459, J5, pL fem; Ам O.72453, K5, dL fem; Ам O.72460, L5, dR hum; AM O.72451, N16, dL tib; Aм O.72457, O15, dR tib; Aм O.72462, ?, pR fem; Aм O.72445, X3, sR fem. Seventeen specimens (including paratypes); MNI, 4.

Layer E: AM O.72479, G2, pL tmt; AM O.72495, G3, sL fem; AM O.72492, I3, dR fem; Ам O.72497, I4, sL tib; Ам O.72499, J4, pR hum; aм O.72502, K4, sR fem; Aм O.72478, L13, d + sR tib; Ам O.72472, L15, sR tib; AM O.72509, M2, dL fem; AM O.72505, M4, dL tmt; AM O.72522, M4, sR fem; Aм O.72491, M14, dR fem; AM O.72496, P1, sR fem; Ам O.72486, P3, dL tib; ам O.72526, Q3, sL fem; Ам O.72488, S4, sL tib; Ам O.72489, T1, pR tmt, pL fem, $\mathrm{dL}$ fem; ам O.72493, T10, R fem; O.72650, T10, pR tib; Ам O.72477, V2, dL tib; ам O.72481, W4, d + sR hum. Twentythree specimens; MNI, 3.

Layer F: ам O.72469, K12, dL fem; Ам O.72471, L11, dR tib; AM O.72473, Y3, p+sR tib; Aм O.72474, F5, pR tib; Aм O.72475, L13, dL tib; Aм O.72482, J3, pR tmt; Ам O.72483, H3, sR fem; Aм O.72487, O14, sR tib; Ам O.72494, F1, sR fem; Aм O.72498, O13, pL tib; AM O.72501, L14, dL tib; Ам O.72506, N13, dL tmt; Ам O.72508, M14, dL tib. Eighteen specimens (including type series); MNI, 3.

Layer G: Aм O.72503, F/G2, pR tmt.

Layer unknown: aм O.72507, F2/G2, (C2 Fe G), p + sL fem.

Total number of specimens, 61; combined MNI, 10.

ETYMOLOgY: The species is named after David Steadman, to reflect the huge contribution he has made to Pacific paleoornithology and to the understanding that Gallirallus-like rails have spawned one of the most spectacular radiations of birds known.

DiAgnosis: A flightless species with leg bones of size similar to that of volant Galli- rallus philippensis (Oceania) or G. striatus (Asia) but that differs from those species by: humerus and ulna, relative to femur size, much smaller; humerus with relatively thinner shaft, less robust tuberculum ventrale, concave dorsal facies adjacent to crista deltopectoralis, and reduced bicipital crest; femur with more elongate tuberculum $\mathrm{m}$. gastrocnemialis lateralis and relatively broader distal tarsi.

DESCRIPTION AND COMPARISON: COMparisons were made with the following specimens of Gallirallus philippensis: Ам O.56994, 59296, 64202, 71174, 72331, 72342, and 70869; and comparative data obtained from Steadman (1987), Steadman et al. (2000), Worthy (2004), and Kirchman and Steadman (2005, 2006a,b, 2007).

Humerus. Although the proximal width is similar to that in humeri of $G$. philippensis (e.g., АM O.70869), the shaft is relatively narrower. Dorsally, the surface between the crista deltopectoralis and the shaft is concave, whereas it is convex in G. philippensis. The caput humeri narrows in caudocranial depth toward its ventral edge, whereas it is widest near the ventral edge in G. philippensis, caused by a distinct bulge overhanging the incisura capitis. In proximal view, the tuberculum ventrale is relatively narrower, and, unlike the fossil, in G. philippensis the tuberculum thickens cranially (i.e., as it approaches the base of the incisura capitis). The crista deltopectoralis is relatively thicker distally and has a deeper sulcus on its ventral side. The crista bicipitalis has a straight distal margin, whereas it is rounded in G. philippensis by a thin protuberant flange. The fossa brachialis is relatively deeper.

Ulna: The ulna is about $20 \%$ shorter than expected given the femur lengths available, the impressio brachialis is relatively more deeply excavated, and the cotyla dorsalis is not hooked distally such that the distocranial margin of the cotyla dorsalis in cranial view is straight. In contrast, in the same aspect, the dorsal side of the cotyla dorsalis in G. philippensis is distinctly hooked distally.

Femur: The femur does not differ appreciably from those of modern G. philippensis (e.g., Aм O.70869), except in the diameter of the tuberculum $\mathrm{m}$. gastrocnemialis lateralis, 
TABLE 3

Summary Statistics of Measurements (mm) of Femora, Tibiotarsi, and Tarsometatarsi of Gallirallus steadmani Worthy \& Bollt, n. sp., and Values for Humeri and an Ulna

\begin{tabular}{|c|c|c|c|c|c|c|c|c|}
\hline Character & $\mathrm{L}$ & PW & $\mathrm{PD}$ & SW & DW & $\mathrm{dLC}$ & $\mathrm{dMC}$ & $\begin{array}{c}\text { DW Dorsal } \\
\text { Condyle }\end{array}$ \\
\hline \multicolumn{9}{|l|}{ Femora } \\
\hline Average & 45.4 & 7.3 & 6.3 & 3.2 & 7.7 & & & \\
\hline SD & 1.29 & 0.37 & 0.38 & 0.17 & 0.12 & & & \\
\hline Count & 3 & 6 & 5 & 12 & 3 & & & \\
\hline Minimum & 44.0 & 6.8 & 5.9 & 2.9 & 7.6 & & & \\
\hline Maximum & 46.5 & 7.8 & 6.9 & 3.4 & 7.8 & & & \\
\hline \multicolumn{9}{|l|}{ Tibiotarsi } \\
\hline Average & & 6.2 & & 2.8 & 6.0 & 5.9 & 6.0 & \\
\hline $\mathrm{SD}$ & & 0.36 & & 0.16 & 0.29 & 0.26 & 0.28 & \\
\hline Count & & 5 & & 9 & 7 & 8 & 6 & \\
\hline Minimum & & 5.6 & & 2.5 & 5.6 & 5.6 & 5.7 & \\
\hline Maximum & & 6.5 & & 3.0 & 6.3 & 6.3 & 6.3 & \\
\hline \multicolumn{9}{|c|}{ Tarsometatarsus } \\
\hline Average & 40.0 & 6.2 & & 3.0 & 6.2 & & & \\
\hline SD & & 0.35 & & 0.12 & & & & \\
\hline Minimum & & 5.9 & & 2.9 & & & & \\
\hline Maximum & & 6.4 & & 3.1 & & & & \\
\hline Count & 1 & 2 & & 3 & 1 & & & \\
\hline Humerus & & $8.4,9.0$ & & $2.3,2.6$ & 5.3 & & & \\
\hline Ulna & 31.5 est. & 3.6 & & 1.7 & 3.6 & & & 3.4 \\
\hline
\end{tabular}

Abbreviations: SD, standard deviation; L, length; PW, maximum proximal width; PD, proximal depth; SW, shaft width at midshaft for femora and tarsometatarsi, minimum values for tibiotarsi; DW, maximum distal width; $\mathrm{dLC}$, anterior-caudal depth lateral condyle; $\mathrm{d} M \mathrm{C}$, anterior-caudal depth medial condyle.

which is as wide as the proximal trochlea fibularis in the fossil but is relatively elongate and narrower than the trochlea in G. philippensis. Such a round tuberculum $\mathrm{m}$. gastrocnemialis lateralis is seen in large flightless Gallirallus species (for example, G. australis [Ам O.53856]), but the elongate form is found in other equally large flightless rails (for example, G. sylvestris [Ам O.56432, 58027, 58028, and 64571]), so it being circular is not related to flightlessness. Available measurements (Table 3) suggest that the Tubuai bird had femora at the small end of the size range for Oceanic G. philippensis (Kirchman and Steadman 2007).

Tibiotarsus: The tibiotarsus does not differ appreciably in shape or size from those of $G$. philippensis, and the size of available specimens is at the small end of the range for Oceanic G. philippensis (Table 3) (Kirchman and Steadman 2007).

Tarsometatarsus: Compared with tarsometatarsi of $G$. philippensis of similar length (e.g., Ам O.70869), those of Gallirallus steadmani have a broader distal end and the fossa parahypotarsalis medialis is shallower proximad of the foramen vasculare proximalia such that it barely forms a notch in the medial facies at the base of the hypotarsus. In $G$. australis, G. sylvestris, and in all G. philippensis examined, the fossa extends to the proximal end and is bound by a ridge, creating a distinct groove medially. However, in the equally large, flightless G. lafresnayanus (Ам B.6147) the fossa did not extend to the proximal end.

Compared with other flightless species of Gallirallus, G. steadmani is larger than $G$. wakensis (Wake Island [Kirchman and Steadman 2006a]), G. pisonii (Aguiguan, Marianas [Kirchman and Steadman 2006a]), and G. modestus (Chatham Islands, New Zealand [Trewick 1997]).

It is smaller than the volant $G$. torquatus (Philippines-New Guinea [Kirchman and Steadman 2007) and the following flightless species: G. owstoni (Guam, Marianas 
[Kirchman and Steadman 2006a]), G. temptatus (Rota, Marianas [Kirchman and Steadman 2006a]), G. pendiculatus (Tinian, Marianas [Kirchman and Steadman 2006a]), G. insignis (New Britain [Kirchman and Steadman 2006a]), G. ernstmayeri (New Ireland, Bismarcks [Kirchman and Steadman 2006a]), G. lafresnayanus (New Caledonia [Ам B.6147]), $G$. sylvestris (Lord Howe Island [AM O.56431]), G. australis (New Zealand [Kirchman and Steadman 2006b]), G. dieffenbachii (Chatham Islands, New Zealand [Trewick 1997]), G. rovianae (New Georgia, Solomon Islands [Kirchman and Steadman 2006a]), G. woodfordi (Isabella, Solomon Islands [Kirchman and Steadman 2006a]), G. poecilopterus (Viti Levu, Fiji [Worthy 2004]), G. vekamatolu ('Eua, Tonga [Kirchman and Steadman 2005]), G. storrsolsoni (Huahine, Society Islands [Kirchman and Steadman 2006b]), and G. roletti (Tahuata, Marquesas [Kirchman and Steadman 2007]).

A few flightless species from Oceania have similar size based on leg bones: the poorly known G. epulare (Nuku Hiva, Marquesas) has similar-sized tibiotarsi but has a relatively shorter ulna, and G. gracilitibia (Ua Huku, Marquesas) has a relatively more reduced humerus (Kirchman and Steadman 2007). Closer to the Austral Islands but still more than $1,000 \mathrm{~km}$ distant, G. buiatua (Niue) has a similar length of tarsometatarsus but is more gracile, with narrower shaft and proximal widths (Steadman et al. 2000). Gallirallus ripleyi (Mangaia, Cook Islands), also with similar distal width of tibiotarsi, has a narrower distal end of the femur, a wider distal end of the tarsometatarsus, and even more greatly reduced wings, with a much shorter ulna and a narrower distal end of the humerus (Steadman 1987, Kirchman and Steadman 2006b).

Gallirallus steadmani is much smaller than the flightless, extremely long-billed Vitirallus (Vitilevu), which otherwise differs in numerous features, including a humerus with a much more reduced crista bicipitalis, crista deltopectoralis rolled over the cranial surface, sulcus extensorius separated from medial margin by wider ridge, and cotylae medialis et lateralis near level with each other, rather than the medial cotyla being appreciably offset proximally from the lateral one (Worthy 2004).

\section{Indeterminate charadriiform 1 MATERIAL: AM O.72530, J9, Layer E, dL fem.}

This specimen is the size of Pluvialis fulva (Pacific Golden-Plover) but differs from that species. It does not appear to be referable to either Heteroscelus incana or Limosa lapponica, and its identity remains indeterminate.

Indeterminate charadriiform 2

MATERIAL: AM O.72467, O3, Layer D, L hum.

Length: estimated length $31.5 \mathrm{~mm}$, distal width $5.2 \mathrm{~mm}$.

This specimen is missing the ventral tubercle and head but preserves the characteristic impressio coracobrachialis and most of the larger crista deltopectoralis. The humerus is smaller than the humerus of Heteroscelus brevipes (ам O.58080) or Calidris acuminata (AM O.71525) but similar to that of Calidris ferriginea (ам O.59867). It differs from humeri of Tringa and Calidris by a more flattened intumescentia humeralis, a broader impressio coracobrachialis, a more proximally located angle on the crista deltopectoralis relative to the junction of the crista bicipitalis and the shaft, and the processus supracondylaris dorsalis is more dorsally directed rather than inclined somewhat cranially. These features and the size appear consistent with Prosobonia cancellatus, as evident in an image of a humerus of this species provided by Mike Dickison (University of Canterbury, pers. comm. to T.H.W., 2009). These initial observations suggest that this humerus possibly might be referable to a Prosobonia species, which genus has several extinct taxa in the eastern Pacific (Steadman 2006), with the remaining species, $P$. cancellata, endangered. Confirmation of this referral awaits future research.

\section{Order Columbiformes Family Columbidae}

Gallicolumba sp. indet., undetermined ground dove 

ulna.

MATERIAL: AM O.72510, I4, Layer E, pL

This specimen is identified as Gallicolumba and distinguished from Ptilinopus by the following features: the cranioventral margin of the cotyla ventralis is angular (curved in Ptilinopus), the crista intercotylaris is high and prominent (much lower in Ptilinopus), the olecranon is low and rounded (higher and pointed in Ptilinopus), and the impressio brachialis is more widely separated from the tuberculum ligamentum collateralis ventralis. The proximal width of this specimen is 4.7 $\mathrm{mm}$, which is similar in size to Gallicolumba jobiensis (Ам O.72023, O.64814). Characterization of the species of Gallicolumba from Atiahara will require additional material.

\section{DISCUSSION}

The Atiahara site on Tubuai in the Austral Islands, French Polynesia, contains a rich Archaic material cultural assemblage (R.B., unpubl. data). The two radiocarbon dates provide calibrated ages of 686-921 yr B.P. and 675-769 yr B.P. for basal layers of the deposit. In addition to these dates, initial habitation, based on the initial appearance of introduced pollen and invertebrates from swamp core samples, dates to between 750 and $850 \mathrm{yr}$ B.P. (M. Prebble and N. Porch, Australian National University, Canberra, pers. comm.). Together, these data indicate that the Atiahara site represents an early phase of habitation on Tubuai dating to the thirteenth-fourteenth centuries A.D., making it contemporaneous with another Archaicperiod site in the valley of Peva on the neighboring island of Rurutu (Bollt 2005a,b, 2007, 2008).

We report 109 identifiable bird bones representing 23 individuals from the Atiahara site (Table 4), which markedly expands the meager record reported by Steadman (2006). A total of 14 indigenous breeding species of birds, dominated by seabirds, is now known

TABLE 4

Total Avifauna Recorded from the Atiahara Site, Tubuai

\begin{tabular}{|c|c|c|c|}
\hline Species & $\begin{array}{l}\text { Steadman } \\
\text { (2006), NISP }\end{array}$ & 2007 NISP & $2007 \mathrm{MNI}$ \\
\hline \multicolumn{4}{|l|}{ Phasianidae } \\
\hline Gallus gallus & 3 & $5+? 1$ & 2 \\
\hline \multicolumn{4}{|l|}{ Procellariidae } \\
\hline Pterodroma sp. magn. P. macroptera & & 1 & 1 \\
\hline Pterodroma sp. magn. P. neglectus & & 2 & 1 \\
\hline Pterodroma sp. magn. P. brevipes & & 9 & 2 \\
\hline Puffinus sp. magn. P. pacificus & & 1 & 1 \\
\hline Puffinus sp. magn. P. lherminieri & 1 & 19 & 3 \\
\hline Pachyptila sp. & 1 & & \\
\hline \multicolumn{4}{|l|}{ Phaethontidae } \\
\hline Phaethon lepturus & 3 & $2+? 2$ & 1 \\
\hline \multicolumn{4}{|l|}{ Columbidae } \\
\hline Gallicolumba sp. indet. & & 1 & 1 \\
\hline Ptilinopus n. sp. & 1 & & \\
\hline \multicolumn{4}{|l|}{ Rallidae } \\
\hline Gallirallus steadmani, n. sp. & & 61 & 10 \\
\hline \multicolumn{4}{|l|}{ Charadriiformes } \\
\hline Anous stolidus & 1 & & \\
\hline Gygis candida & 1 & & \\
\hline Indeterminate sp. et gen. 1 & & 1 & 1 \\
\hline Indeterminate sp. et gen. 2 & & 1 & 1 \\
\hline Totals & 11 & 109 & 23 \\
\hline
\end{tabular}

Abbreviations: NISP, number of individual specimens; MNI, minimum number of individuals. 
from the island. In the fossil assemblage, petrels (Procellariidae) are the most diverse group, and included are at least three species of Pterodroma and two species of Puffinus. The small Puffinus sp. magn. P. Iherminieri and the small Pterodroma sp. magn. P. brevipes were relatively abundant in the assemblage, which indicates that these taxa almost certainly had breeding populations on the island. Similarly, the medium-sized petrel Pterodroma sp. magn. P. neglectus is represented by juvenile bones of an unfledged chick, also indicating breeding. Most of the other petrel taxa are widespread in the Pacific and may have either bred or been visitors to the island, with the exception of a bone of Pachyptila, a genus that breeds in southern oceans at latitudes higher than $45^{\circ}$, so that a breeding colony in the Austral Islands is most unlikely, contra Steadman (2006:401). Instead, the specimen more likely represents a vagrant attracted to the island by large populations of other petrels (Worthy 2007). Various species of Pachyptila regularly range into the tropical Pacific during their nonbreeding seasons (Gill et al. 2010), so rare bones from such vagrant individuals might be expected in samples from islands with former significant petrel populations.

The terns Gygis and Anous spp. and the tropicbird Phaethon lepturus are widely recorded in Oceania (Steadman 2006), so their presence as reported by Steadman (2006) is not unexpected. What is more surprising is the general lack of diversity of land birds, with only four species, of which Gallus is a human-transported taxon, in the deposit (Steadman 2006; data herein [Table 4]).

One of these, however, a small, endemic, flightless species of Gallirallus, dominates the fauna in terms of specimens recovered, with 61 bones of 10 individuals, and adds to the diversity of the genus, which has recently been shown to have been rich in endemic species across the Pacific (Steadman 1987, 2006, Steadman et al. 2000, Worthy 2004, Kirchman and Steadman 2005, 2006a,b, 2007).

Evolution of flightless distinct rails has at times been rapid (for example, Porzana atra on Henderson Island, which island has only been subaerial for about $380 \mathrm{kyr}$ [Blake
1995], and other examples given by Slikas et al. [2002]). Many of the Gallirallus-group species were thought to have been derived from a volant ancestor like Gallirallus philippensis, for example (Steadman 2006). Recently, Kirchman (2009) demonstrated that for the more distinctive taxa, the extant $G$. philippensis is not their direct ancestor. However, a few fossil taxa, little different from $G$. philippensis but still flightless, make G. philippensis as currently construed appear to be paraphyletic. Reasons for such paraphyly among distinctive taxa can include recent or past hybridization events and incomplete lineage sorting, as reviewed by Joseph and Omland (2009), and were in part invoked by Kirchman (2009) to explain the data. Gallirallus steadmani, described herein, is another flightless taxon that is about as distinct from $G$. philippensis as the various Marianas species (Kirchman and Steadman 2006a, Kirchman 2009), so it may conceivably be closely related to the G. philippensis radiation, or more likely because of its geographic location it may be a sister species to $G$. ripleyi of Mangaia and G. buiatua of Niue and derived from an earlier spreading volant ancestor. It is likely that other islands in the Austral group will have endemic rails when faunas are forthcoming.

The remaining land birds, both very scarce, are small pigeons of the genera Gallicolumba and Ptilinopus, neither of which occurs on Tubuai today, although Ptilinopus buttoni occurs on Rapa (Steadman 2006). Several bones of a species of Gallicolumba have been reported from Peva on Rurutu (Steadman and Bollt 2010). It is likely, therefore, that before human arrival in the Austral group, species of Ptilinopus and Gallicolumba existed on each of the larger islands. That the fossil Ptilinopus recorded by Steadman (2006) from Tubuai differs from extant $P$. buttoni of Rapa suggests that perhaps at least each of the larger islands (Rimatara, Rurutu, Tubuai, Raivavae, and Rapa) had endemic taxa of these genera, with the only survivor being P. buttoni on Rapa.

The archaeological material is almost certainly an incomplete sample of the fauna before human occupation because bones of the 
lorikeet Vini and reed warbler Acrocephalus were not found, although both genera are known elsewhere in the Australs and almost certainly had populations on Tubuai. Thus, further archaeological material will almost certainly increase the known diversity of the prehistoric avifauna of Tubuai.

In addition to the avifauna, three Pteropus bones were recovered from the Atiahara site, one of which could be identified as Pteropus tonganus tonganus. This supports the identification by Weisler et al. (2006) of an edentulous dentary from the adjacent island of Rurutu as $P$. tonganus. This is important because the edentulous mandible described by Weisler et al. could possibly have been another similar-sized species such as $P$. samoensis. The recent discovery of two further Pteropus species among historically collected material (Helgen et al. 2009), both now presumed extinct, shows that Samoa formerly had four sympatric species. The new species are considerably smaller $(P$. coxi) or considerably larger and more robust ( $P$. allenorum) than the Tubuai specimens. The evidence to hand suggests that these far-eastern pteropids were Pteropus tonganus tonganus.

\section{ACKNOWLEDGMENTS}

R.B. thanks the community of Tubuai for its help, and specifically the proprietor of Atiahara, Wilson Doom, and his wife Giselle. He thanks his friends Lawrence and Tera Miller, without whom the excavation would not have been possible. In addition, he thanks his wonderful crew (in no order of importance whatsoever): Jeff Putzi, Ben Shaw, Tanner Amdur-Clark, Adam Thompson, Siobhan Durcan, Jen Heubert, Daniela Serra, Marianne Turner, Rosanne Hawarden, Katarina Boljikovac, and R.B.'s wife Oana. They were the backbone of the expedition with their amazing, intelligent, enthusiastic, and boundless support and energy. He thanks as well the Service de la culture et du Patrimoine and the Musée de Tahiti et ses Iles, specifically Tamara Maric and Belona Mou, who worked ceaselessly to make everything possible. We thank collaborators Matiu Prebble and Nick Porch for funding the two AMS radiocarbon dates from the Atiahara site as part of their Australian Research Council DP0878694 project. For access to collections, T.H.W. thanks Philippa Horton, South Australian Museum, and Walter Boles, Australian Museum. We thank Storrs Olson and another reviewer for their comments that substantially improved the text.

\section{Literature Cited}

Aitken, R. 1930. Ethnology of Tubuai. Bernice P. Bishop Mus. Bull. 70.

Allen, M. S. 1992. Temporal variation in Polynesian fishing strategies: The southern Cook Islands in regional perspective. Asian Perspect. 31:183-204.

Austin, J. J., V. Bretagnolle, and E. Pasquet. 2004. A global molecular phylogeny of the small Puffinus shearwaters and implications for systematics of the little-Audubon's shearwater complex. Auk 121:847-864.

Baumel, J. J., and L. M. Witmer. 1993. Osteologia. Pages 45-132 in J. J. Baumel, A. S. King, J. E. Breazile, H. E. Evans, and J. C. Vanden Berge, eds. Handbook of avian anatomy: Nomina anatomica avium. 2nd ed. Publications of the Nuttall Ornithological Club, no. 23. Cambridge, Massachusetts.

Blake, S. G. 1995. Late Quaternary history of Henderson Island, Pitcairn Group. Pages 43-62 in T. G. Benton and T. Spencer, eds. The Pitcairn Islands: Biogeography, ecology and prehistory. Academic Press, London.

Bollt, R. 2005a. Peva: The archaeology of a valley on Rurutu, Austral Islands, East Polynesia. Ph.D. diss., University of $\mathrm{Ha}-$ wai'i at Mānoa, Honolulu.

. 2005b. Recherche sur le site de Peva, Rurutu, îles Australes. Pages 202-208 in Bilan de la recherche archéologique en Polynésie française 2003-2004. Dossier d'Archéologie Polynésienne no. 4, Ministère de la culture de Polynésie française, Service de la culture et du patrimoine.

- 2007. Excavations in Peva Valley, Rurutu, Austral Islands (East Polynesia). Asian Perspect. 47 (1): 156-187.

. 2008. Peva: The archaeology of an 
Austral Island settlement. Bishop Mus. Bull. Anthropol. 12.

Bourne, W. R. P. 1986. A new Little Shearwater from the Tubuai Islands: Puffinus assimilis myrtae subsp. nov. Emu 59:213215.

Carboneras, C. 1992. Family Procellariidae (petrels and shearwaters). Pages 216-271 in J. Del Hoyo, A. Elliott, and J. Sargatal, eds. Handbook of the birds of the world. Ostrich to ducks. Vol. 1. Lynx Edicions, Barcelona.

Eddowes, M. 1998. Initial results from Atiahara and Teta'itapu, two coastal settlement sites, upon the islands of Tubuai and Tahiti: Their implications for an understanding of prehistoric regional adaptation to environment. Pages 7-30 in P. Vargas Casanova, ed. Easter Island and East Polynesian prehistory. Universidad de Chile, Santiago.

Ehrhardt, J. P. 1980. L'avifaune de Tubuaï. Cah. Indo Pac. 2:271-288.

Flannery, T. F. 1995. Mammals of the SouthWest Pacific and Moluccan Islands. Reed Books, Chatswood, New South Wales, Australia.

Gill, B. J., B. D. Bell, G. K. Chambers, D. G. Medway, R. L. Palma, R. P. Scofield, A. J. D. Tennyson, and T. H. Worthy. 2010. Checklist of the birds of New Zealand, Norfolk and Macquarie islands, and the Ross Dependency, Antarctica. 4th ed. Ornithological Society of New Zealand and Te Papa Press, Wellington, New Zealand.

Helgen, K. M., L. E. Helgen, and D. E. Wilson. 2009. Pacific flying foxes (Mammalia: Chiroptera): Two new species of Pteropus from Samoa, probably extinct. Am. Mus. Novit. 3646:1-37.

Henry, T. 1928. Ancient Tahiti. Bernice P. Bishop Mus. Bull. 48.

Joseph, L., and K. E. Omland. 2009. Phylogeography: Its development and impact in Australo-Papuan ornithology with special reference to paraphyly in Australian birds. Emu 109:1-23.

Kennett, D., A. J. Anderson, M. Prebble, E. Conte, and J. Southon. 2006. Prehistoric human impacts on Rapa, French Polynesia. Antiquity 80:340-354.
Kirchman, J. J. 2009. Genetic tests of rapid parallel speciation of flightless birds from an extant volant ancestor. Biol. J. Linn. Soc. 96:601-616.

Kirchman, J. J., and D. W. Steadman. 2005. Rails (Aves: Rallidae: Gallirallus) from prehistoric sites in the Kingdom of Tonga, including a description of a new species. Proc. Biol. Soc. Wash. 118:465-477.

—. 2006a. Rails (Rallidae: Gallirallus) from prehistoric archaeological sites in western Oceania. Zootaxa 1316:1-31.

. 2006b. New species of rails (Aves: Rallidae) from an archaeological site on Huahine, Society Islands. Pac. Sci. 60:281297.

. 2007. New species of extinct rails (Aves: Rallidae) from archaeological sites in the Marquesas Islands, French Polynesia. Pac. Sci. 61:145-163.

Livezey, B. C., and R. L. Zusi. 2006. Higherorder phylogeny of modern birds (Theropoda, Aves: Neornithes) based on comparative anatomy. I. Methods and characters. Bull. Carnegie Mus. Nat. Hist. 37:1-544.

Onley, D., and R. P. Scofield. 2006. A fieldguide to the albatross and petrels of the world. Helm, London.

Pratt, H. D., P. L. Bruner, and D. G. Berrett. 1987. A field guide to the birds of Hawaii and the tropical Pacific. Princeton University Press, Princeton, New Jersey.

Slikas, B., S. L. Olson, and R. C. Fleischer. 2002. Rapid independent evolution of flightlessness in four species of Pacific island rails (Rallidae): An analysis based on mitochondrial sequence data. J. Avian Biol. 33:5-14.

Steadman, D. W. 1987. Two new species of rails (Aves: Rallidae) from Mangaia, southern Cook Islands. Pac. Sci. 40:38-54.

- 1991. Extinct and extirpated birds from Aitutaki and Atiu, southern Cook Islands. Pac. Sci. 45:325-347. . 2006. Extinction and biogeography of tropical Pacific birds. University of Chicago Press, Chicago.

Steadman, D. W., and R. Bollt. 2010. Prehistoric birds from Rurutu, Austral Islands, East Polynesia. Pac. Sci. 64:315-325.

Steadman, D. W., T. H. Worthy, A. J. Anderson, and R. Walter. 2000. New species 
and records of birds from prehistoric sites on Niue, Southwest Pacific. Wilson Bull. 112:165-186.

Thibault, J.-C., and V. Bretagnolle. 2007. Atlas des oiseaux marins nicheurs de Polynésie française et du Groupe Pitcairn. 2 vols. Société d'Ornithologie de Polynésie et Direction de l'Environnement de la Polynésie française.

Trewick, S. A. 1997. Sympatric flightless rails Gallirallus dieffenbachii and G. modestus on the Chatham Islands, New Zealand: Morphometrics and alternative evolutionary scenarios. J. R. Soc. N. Z. 27:451-464.

Walter, R. 1996. What is the East Polynesian 'Archaic'? A view from the Cook Islands. Pages 512-529 in J. M. Davidson, G. Irwin, B. F. Pawley, and D. Brown, eds. Oceanic culture history: Essays in honour of Roger Green. N. Z. J. Archaeol. Spec. Publ.
1998. Anai'o: The archaeology of a fourteenth century Polynesian community in the Cook Islands. N. Z. Archaeol. Assoc. Monogr. 22.

Warham, J. 1990. The petrels: Their ecology and breeding systems. Academic Press, London.

Weisler, M. I., R. Bollt, and A. Findlater. 2006. A new eastern limit of the Pacific Flying Fox, Pteropus tonganus (Chiroptera: Pteropodidae) in prehistoric Polynesia: A case of possible human transport and extirpation. Pac. Sci. 60:403-411.

Worthy, T. H. 2004. The fossil rails (Aves: Rallidae) of Fiji with descriptions of a new genus and species. J. R. Soc. N. Z. 34:295-314.

. 2007. Extinction and biogeography of tropical Pacific birds. Invited review. Emu 107:248-251. 
